\title{
INOKULASI SUSPENSI AKTIF PADA BIOSISTEM VERTIKAL DENGAN TUMBUHAN RUMPUT GAJAH (Pennisetum purpureum) DALAM PENURUNAN KADAR METILEN BIRU, Cd DAN Cr TOTAL
}

\author{
I W. B. Suyasa*, N. G. A. M. D. A. Suastuti, dan I G. M. A. P. Raharja \\ Program Studi Kimia FMIPA Universitas Udayana, Bukit Jimbaran, Bali 80361 \\ *Email: budiarsa_suyasa@unud.ac.id
}

\begin{abstract}
ABSTRAK
Pada penelitian ini, dilakukan pengukuran kadar metilen biru, logam berat $\mathrm{Cd}$, dan $\mathrm{Cr}$ total dalam air limbah artificial dengan menggunakan suspensi aktif pada biosistem vertikal menggunakan rumput gajah. Penelitian ini bertujuan untuk menentukan suspensi aktif terbaik yang ditumbuhkan dari sumber nutrien yang berbeda (nutrien NPK, pupuk NPK, dan molase), ditentukan efektivitas dan kapasitas biosistem, serta menentukan pengaruh jumlah waktu retensi hidrolik biosistem. Metode yang digunakan yaitu dengan mengalirkan limbah artificial secara kontinyu dalam bak biosistem yang diinokulasi suspensi aktif sebanyak 3 kali waktu retensi hidrolik. Metode analisis yang digunakan yaitu metode uji-t deskriptif. Hasil penelitian menunjukkan suspensi aktif terbaik diperoleh dari sampel tanah dengan sumber nutrien NPK dan pupuk NPK (pasaran) dengan pertumbuhan biomassa mencapai $1200 \mathrm{mg} / \mathrm{L}$ pada waktu $18 \mathrm{jam}$. Efektivitas biosistem vertikal tumbuhan rumput gajah dengan pupuk NPK dalam menurunkan kadar zat warna metilen biru, $\mathrm{Cd}$, dan $\mathrm{Cr}$ berturut-turut sebesar $99,7587 \%$, 99,8011\%, dan 63,4927\%. Kapasitas maksimum dalam menurunkan metilen biru, Cd, dan Cr total berturut-turut sebesar $2,7512 \times 10^{3} \mathrm{mg} / \mathrm{m}^{3}, 3,2220 \times 10^{3} \mathrm{mg} / \mathrm{m}^{3}$, dan $2,2842 \times 10^{3} \mathrm{mg} / \mathrm{m}^{3}$. Pengaruh jumlah waktu retensi hidrolik biosistem vertikal tumbuhan rumput gajah berdasarkan uji-t yaitu sudah mampu menurunkan kadar limbah metilen biru hingga $\leq 5 \mathrm{ppm}$ dalam 1 kali waktu retensi hidrolik dan menurunkan kadar $\mathrm{Cd} \leq 0,05$ ppm dalam 3 kali waktu retensi hidrolik. Akan tetapi system ini tidak mampu menurunkan kadar $\mathrm{Cr}$ total $\leq 1 \mathrm{ppm}$.
\end{abstract}

Kata kunci: biosistem, efektivitas, kapasitas, inokulasi, dan suspensi aktif

\begin{abstract}
This research paper discusses the determination of activated suspension on vertical biosystem with Pennisetum purpureum in decreasing the content of methylene blue, $\mathrm{Cd}$, and $\mathrm{Cr}$ in wastewater. The aims of this research were to determine the best activated suspension from different sources of nutrient (NPK nutrient, NPK fertilizer, and molasses), the effectiveness and capacity of biosystem, and the impact of the amount of hydraulic retention time of the biosystem. The method used was flowing the artificial wastewater continuously into the biosystem tub which inoculated with active suspension in 3 times of hydraulic retention time. The method of analysis used was that of the descriptive t-test. The result showed that the best active suspension was obtained from soil sample with NPK nutrient and NPK fertilizer (market quality) as the nutrient source with a biomass growth of $1200 \mathrm{mg} / \mathrm{L}$ at 18 hours. The effectiveness of the vertical biosystem of Pennisetum purpureum with NPK fertilizer as the nutrient source in decreasing the concentration of methylene blue, heavy metal $\mathrm{Cd}$ and total $\mathrm{Cr}$ for each tub were of $99.7587 \%$; $99.8011 \%$ and $63.4927 \%$, respectively. The maximum capacity in decreasing the contents of methylene blue, $\mathrm{Cd}$, and total $\mathrm{Cr}$ for each tub were of $2.7512 \times 10^{3} \mathrm{mg} / \mathrm{m}^{3} ; 2.2842 \times 10^{3} \mathrm{mg} / \mathrm{m}^{3}$, and $2.2842 \times 10^{3} \mathrm{mg} / \mathrm{m}^{3}$, respectively. Based on the t-test analysis, the effect of the amount of hydraulic retention time of the vertical biosystem of Pennisetum purpureum was that the system could decrease the concentration of methylene blue to the level of $\leq 5 \mathrm{ppm}$ in 1 time hydraulic retention time and also decreased the concentration of $\mathrm{Cd}$ to $\leq 0.05 \mathrm{ppm}$ in 3 times hydraulic retention time. However, this system could not decrease the total concentration of $\mathrm{Cr}$ of $\leq 1 \mathrm{ppm}$.
\end{abstract}

Keywords: active suspension, biosystem, capacity, efectivity. inoculation

\section{PENDAHULUAN}

$\begin{array}{crcr}\text { Sebagian } & \begin{array}{c}\text { besar } \\ \text { limbah }\end{array} & \text { industri } & \text { tekstil } \\ \text { pencemar } & \text { yang }\end{array}$

mengandung zat warna hasil pencelupan yang umumnya merupakan zat warna sintetik yang kurang ramah lingkungan. Salah satu jenis zat 
warna sintetik yang digunakan yaitu metilen biru. Dampak yang ditimbulkan tercemarnya metilen biru pada perairan yaitu dapat menyebabkan mutasi genetik dan berpengaruh pada reproduksi. (Hawley, 1981). Industri tekstil juga menghasilkan limbah pencemar yang mengandung logam berat, diantaranya logam berat krom (Cr) dan kadmium (Cd). Kromium besifat karsinogenik dan berwarna putih (Avudainayagam et al, 2003), sedangkan logam kadmium dapat menyebabkan terjadinya kerusakan ginjal, gangguan pada tulang, dan anemia (Fortsner dan Witmann, 1983). Oleh karena itu, untuk menanggulangi adanya pencemaran harus dilakukan pengolahan limbah terlebih dahulu.

Salah satu pengolahan limbah dapat dilakukan secara biologi, umumnya menggunakan mikroorganisme. Mikroorganisme dapat dibuat dalam bentuk suspensi aktif), suspensi tersebut bertugas mengikat substrat organik kemudian menguraikannya menjadi lebih sederhana (Suyasa, 2011). Akan tetapi pengolahan limbah dengan menggunakan mikroorganisme memiliki kelemahan yaitu tingkat aktivitas mikroorganisme dalam mengolah limbah kurang optimal. Oleh karena itu diperlukan suatu alternatif untuk mengoptimalkan aktifitas mikroorganisme dalam mengolah limbah yaitu dengan biosistem.

Dalam biosistem diperlukan media pertumbuhan yang umumnya mengandung sumber C, N, P, K. Dalam hal ini sumber C bisa didapat pada glukosa, molase, dan lainlain. Untuk sumber $\mathrm{N}, \mathrm{P}$, dan $\mathrm{K}$ bisa dipakai bahan kimia dan pupuk pasaran. Penelitian yang dilakukan oleh Hartesa (2016) menggunakan bahan kimia dan glukosa sebagai media dalam pembuatan suspensi aktif terbaik. Penelitian menggunakan pupuk pasaran dan glukosa dalam pembuatan media dilakukan oleh Gosal (2017).

Beberapa penelitian pengolahan limbah dengan menggunakan biosistem telah banyak dilakukan, diantaranya penelitian Meita (2015) dengan biosistem tanaman kangkungan mampu menurunkan kadar fenol, ammonia, ion klorida dan COD yaitu sebesar 0,2906 mg/L, 0,1452 mg/L, 2,127 mg/L, dan $3,848 \mathrm{mg} / \mathrm{L}$. Hasil penelitian menggunakan biosistem tanaman talas dapat menurunkan zat warna remazol black b sebesar 97,82\% (Hartesa, 2016). Dalam penelitian Kriswidatari (2016) dilaporkan bakteri yang berperan dalam penurunan zat warna remazol brilliant blue yaitu Pseudomonas sp., Aeromonas sp., Plesiomonas sp.

Dalam penelitian ini, penurunan kadar metilen biru, kadmium (Cd) dan krom ( $\mathrm{Cr}$ ) total dilakukan dengan inokulasi suspensi aktif pada biosistem vertikal dengan menggunakan rumput gajah dalam pengolahan air limbah artificial. Sistem pengolahan limbah ini diharapkan mampu mengurangi kadar pencemar dengan efektif dan efisien.

\section{MATERI DAN METODE}

\section{Bahan}

Bahan-bahan yang digunakan dalam penelitian ini yaitu glukosa, $\mathrm{K}_{2} \mathrm{HPO}_{4}, \mathrm{MgSO}_{4}$, $\mathrm{FeSO}_{4}, \quad \mathrm{KH}_{2} \mathrm{PO}_{4}, \quad\left(\mathrm{NH}_{4}\right)_{2}\left[\mathrm{Fe}\left(\mathrm{SO}_{4}\right)\right]_{2} \cdot 6 \mathrm{H}_{2} \mathrm{O}$, ekstrak ragi, tanaman, sampel tanah, kertas saring Whatman 42 ukuran pori $0,45 \mu \mathrm{m}$, batu koral, pasir, metilen biru, aquades, $\mathrm{HNO}_{3}$, $\mathrm{Cd}\left(\mathrm{NO}_{3}\right)_{2}, \mathrm{H}_{2} \mathrm{SO}_{4}, \mathrm{~K}_{2} \mathrm{Cr}_{2} \mathrm{O}_{7}$.

\section{Peralatan}

Alat-alat yang digunakan dalam penelitian ini yaitu aerator, aluminium foil, kapas, autoklaf, bak biofiltrasi, batang pengaduk, bola hisap, gelas beker, gelas ukur, desikator, kain kasa, kulkas, labu ukur, oven, pipet tetes, pipet volume, tanur, neraca analitik, cawan porselin spektrofotometri UVVis 1800 Shimadzu, spektrofotometri AAS, timbangan.

\section{CARA KERJA}

\section{Penyediaan rumput gajah (Pennisetum purpureum)}

Rumput gajah diambil seluruh bagian dari akar sampai batangnya. Bagian akar dari tumbuhan dicuci hingga bersih, selanjutnya ditanam dalam pot tanaman yang telah berisi batu dan pasir selama 1 bulan. Setelah tumbuh dengan baik, rumput gajah dipindahkan ke dalam bak biosistem dan diadaptasikan lagi selama 4-5 hari.

\section{Pengambilan sampel tanah}

Pengambilan sampel tanah dilakukan di sungai dekat tempat pembuangan limbah pencelupan yang berlokasi di jalan Mahendradata. Sampel diambil di 3 titik dengan asumsi dapat mewakili 1 tempat dengan berat 100 gram dengan kedalaman 15$20 \mathrm{~cm}$ dari permukaan. Sampel yang didapat dimasukkan ke dalam kantong plastik yang 
telah berisi label kemudian disimpan dalam ice box.

\section{Pembuatan limbah artificial}

Larutan metilen biru 1000 ppm, Cd 500 ppm, dan $\mathrm{Cr} 500$ ppm masing-masing sebanyak $450 \mathrm{~mL}, 900 \mathrm{~mL}$, dan $900 \mathrm{~mL}$ dimasukkan kedalam jerigen dengan volume $30 \mathrm{~L}$, kemudian diencerkan dengan air hingga tanda batas. Setelah dicampurkan diperoleh limbah artificial dengan kadar metilen biru, $\mathrm{Cd}$, dan Cr masing-masing sebesar 15 ppm.

\section{Pembuatan media cair (nutrien)}

\section{- Media Cair NPK}

Bahan-bahan yang digunakan dalam pembuatan media cair (nutrien) yaitu 2 gram glukosa ; 0,1 gram $\mathrm{K}_{2} \mathrm{HPO}_{4} ; 0,1$ gram $\mathrm{KH}_{2} \mathrm{PO}_{4} ; 0,1$ gram $\left(\mathrm{NH}_{4}\right)_{2}\left[\mathrm{Fe}\left(\mathrm{SO}_{4}\right)_{2}\right] \cdot 6 \mathrm{H}_{2} \mathrm{O}$; 0,02 gram $\mathrm{MgSO}_{4} ; 0,02$ gram $\mathrm{FeSO}_{4} ; 0,02$ gram ekstrak ragi; $20 \%$ limbah artificial. Bahan-bahan tersebut dicampur kemudian dilarutkan dengan aquades ke dalam labu ukur 2L hingga tanda batas (Waluyo,2009).

- Media cair pupuk NPK (pasaran)

Sebanyak 0,2 gram pupuk NPK dimasukkan kedalam labu ukur 2 L, kemudian ditambahkan dengan gula pasir sebanyak 2 gram dan limbah artificial 20\% dan dilarutkan hingga tanda batas.

- Media cair molase

Sebanyak 4 gram molase dimasukkan kedalam labu ukur 2L, kemudian ditambahkan dengan gula pasir sebanyak 2 gram dan limbah artificial 20\% dan dilarutkan hingga tanda batas.

Ketiga media disterilisasi dengan autoklaf selama 15 menit pada suhu $121^{\circ} \mathrm{C}$. Media yang telah disterilisasi didiamkan selama 5 menit pada suhu $37^{\circ} \mathrm{C}$ kemudian disimpan pada kulkas sampai saat diperlukan (Ginting,2007).

\section{Pembibitan suspensi aktif}

Masing-masing media cair (nutrien) sebanyak 1 L dimasukkan kedalam gelas beker, kemudian ditambah sampel tanah masing-masing sebanyak 1 gram. Selanjutnya diaerasi dengan variasi waktu 12, 18, 24, 36, 42, 48, 60, 66, dan 72 jam kemudian dilakukan pengukuran nilai VSS.

\section{Penentuan nilai VSS (Volatile suspended solids)}

Sebanyak 3 cawan porselin dikeringkan dalam oven pada suhu $100^{\circ} \mathrm{C}$. Masing-masing cawan dimasukkan 25,0 mL larutan bibit yang telah diaerasi. Cawan yang berisi sampel dikeringkan dalam oven pada suhu $105{ }^{\circ} \mathrm{C}$ selama \pm 3 jam, kemudian didinginkan dalam desikator dan ditmbang hingga berat konstan. Selanjutnya dikeringkan dalam tanur pada suhu $600{ }^{\circ} \mathrm{C}$ selama 1 jam hingga berat konstan. Penentuan nilai VSS dapat dilakukan dengan cara :

$$
\mathrm{VSS}=(\mathrm{A}-\mathrm{B}) / \mathrm{V} \times 10^{6} \mathrm{mg} / \mathrm{L}
$$

Keterangan :

$\mathrm{A}=$ berat cawan dan residu sebelum pembakaran $600{ }^{\circ} \mathrm{C}$ (gram)

$\mathrm{B}=$ berat cawan dan residu setelah pembakaran $600{ }^{\circ} \mathrm{C}$ (gram)

$\mathrm{v}=$ volume larutan bibit $(\mathrm{mL})$

\section{Penentuan efektivitas dan kapasitas biosistem vertikal tumbuhan rumput gajah dalam menurunkan kadar metilen biru, Cd, dan Cr total}

Bak biosistem sebanyak 3 buah disiapkan dengan ukuran tinggi $51 \mathrm{~cm}$ dengan diameter bawah $28 \mathrm{~cm}$ dan diameter atas 34 $\mathrm{cm}$. Masing-masing bak diisi dengan media batu koral setinggi $15 \mathrm{~cm}$, pasir setinggi 36 $\mathrm{cm}$, serta rumput gajah. Masing-masing bak dimasukkan suspensi aktif terbaik sebelum dialiri limbah artificial. Suspensi aktif diadaptasikan dengan biosistem vertikal tumbuhan rumput gajah tersebut selama 1 hari, selanjutnya dialiri dengan limbah artificial secara kontinyu. Filtrat yang dikeluarkan dari biosistem vertikal ditampung dan dilakukan pengujian kadar metilen biru, $\mathrm{Cd}$, dan $\mathrm{Cr}$ total. Proses pengaliran dilakukan sebanyak 3 kali atau dilakukan 3 kali waktu retensi hidrolik. Efektivitas pengolahan dari inokulasi suspensi aktif pada biosistem vertikal menggunakan rumput gajah dapat dihitung berdasarkan efektivitas proses yang terjadi, yaitu dengan dapat dilakukan dengan rumus :

$\%$ Efektivitas $=(\mathrm{A}-\mathrm{B}) / \mathrm{A} \times 100 \%$

Keterangan

$\mathrm{A}=$ Kadar metilen biru, Cd, dan Cr total awal

$\mathrm{B}=$ Kadar metilen biru, $\mathrm{Cd}, \mathrm{Cr}$ total akhir

Selanjutnya kapasitas biosistem

vertikal tumbuhan rumput gajah dalam mendegradasi limbah artificial dapat 
ditentukan dengan rumus :

Kapasitas $=(\mathrm{A}-\mathrm{B}) \times \mathrm{V}_{\text {limbah }} / \mathrm{V}$

$\mathrm{A}=$ Kadar metilen biru, $\mathrm{Cd}$, dan Cr total awal

$\mathrm{B}=$ Kadar metilen biru, Cd, Cr total akhir

$\mathrm{V}=$ Volume media penyerap $\left(\mathrm{m}^{3}\right)$

\section{Analisis data}

Analisis data hasil penelitian digunakan untuk menguji perbedaan rata-rata suatu sampel pada masing-masing parameter dengan suatu nilai hipotesis. Teknik yang digunakan dalam analisis ini yaitu teknik uji-t deskriptif (satu sampel).

\section{Penentuan suspensi aktif terbaik}

Penentuan suspensi aktif terbaik dilakukan dengan pembibitan sampel tanah dengan variasi sumber nutrien, sumber nutrien yang digunakan yaitu nutrien NPK, nutrien pupuk NPK (pasaran), dan nutrien molase. Pembibitan suspensi aktif bertujuan untuk mengetahui tingkat pertumbuhan biomassa pada sampel tanah dengan variasi sumber nutrien. Pertumbuhan biomassa diamati selama 3 hari dengan waktu aerasi pada jam ke $12,18,24,36,42,48,60,66$, dan 72. Hasil penentuan nilai VSS pada jam ke 12, 18, 24, $36,42,48,60,66$, dan 72 dapat dilihat pada Gambar 1.

\section{HASIL DAN PEMBAHASAN}

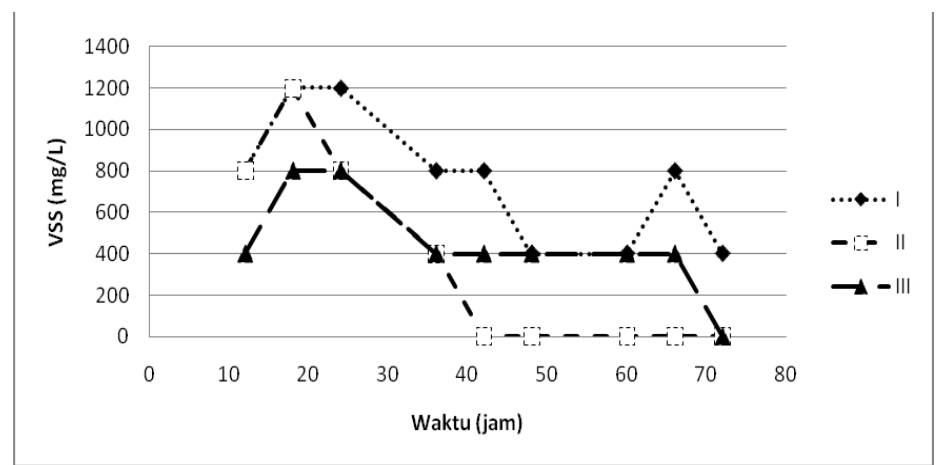

Gambar 1. Kurva Pertumbuhan Biomassa $(I=$ pupuk NPK, II = NPK, III = molase $)$

Dari Gambar 1. dapat dilihat bahwa untuk ketiga variasi media nutrien terjadi peningkatan dan penurunan biomassa selama 72 jam. Puncak pertumbuhan biomassa terjadi pada waktu 18 jam, dengan nilai VSS pada pupuk NPK (pasaran), NPK, dan molase masing-masing sebesar $1200 \mathrm{mg} / \mathrm{L}, 1200$ $\mathrm{mg} / \mathrm{L}$, dan $800 \mathrm{mg} / \mathrm{L}$. Adanya peningkatan biomassa tersebut kemungkinan disebabkan oleh aktivitas mikroorganisme. Aktivitas mikroorganisme ditunjukkan dengan terbentuknya sel baru yang disebabkan oleh adanya pembelahan sel dalam sistem suspensi aktif (Soeparno,1992). Selanjutnya masingmasing suspensi aktif dengan variasi sumber nutrien mengalami penurunan. Nilai VSS terkecil pada suspensi aktif dengan sumber nutrien pupuk NPK (pasaran), NPK, dan molase berturut-turut yaitu sebesar $400 \mathrm{mg} / \mathrm{L}$, $0 \mathrm{mg} / \mathrm{L}$, dan $0 \mathrm{mg} / \mathrm{L}$. Hal tersebut menunjukkan bahan-bahan organik telah habis didegradasi oleh mikroorganisme dan mikroorganisme tidak dapat membentuk sel baru dan mati disebabkan karena kehabisan nutrisi (Atlas and Bartha, 1987). Data tersebut menunjukkan bahwa suspensi aktif yang berasal dari sampel tanah dengan sumber nutrien NPK dan pupuk NPK (pasaran) terbaik pada jam ke-18. Dipilihnya sumber nutrien pupuk NPK (pasaran) dibandingkan sumber nutrien NPK karena segi ekonomis, sumber nutrien pupuk NPK lebih murah daripada sumber nutrien NPK dan juga lebih mudah didapat karena beredar di pasaran.

\section{Efektivitas dan kapasitas biosistem vertikal dalam menurunkan kadar metilen biru}

Pada penelitian ini digunakan bak biosistem yang telah berisi suspensi aktif terbaik dengan sistem 3 kali waktu retensi hidrolik dalam mengolah limbah artificial. Dalam 1 kali waktu retensi hidrolik dibutuhkan waktu sebesar 1 jam 50 menit untuk mengalirkan air limbah artificial. Pengolahan ini dilakukan sebanyak 2 kali pengulangan, hasil yang yang diperoleh dapat dilihat pada Tabel 1. dan Gambar 2. 
Tabel 1. Kadar Metilen Biru Dalam Limbah

\begin{tabular}{cc}
\hline Perlakuan & Kadar Metilen Biru Rata-Rata $(\mathrm{ppm}) \pm$ SD \\
\hline Limbah Awal & $11,8264 \pm 0$ \\
1 kali waktu retensi hidrolik & $0,1518 \pm 0,0925$ \\
kali waktu retensi hidrolik & $0,0397 \pm 0,0107$ \\
3 kali waktu retensi hidrolik & $0,0285 \pm 0,0042$ \\
\hline
\end{tabular}

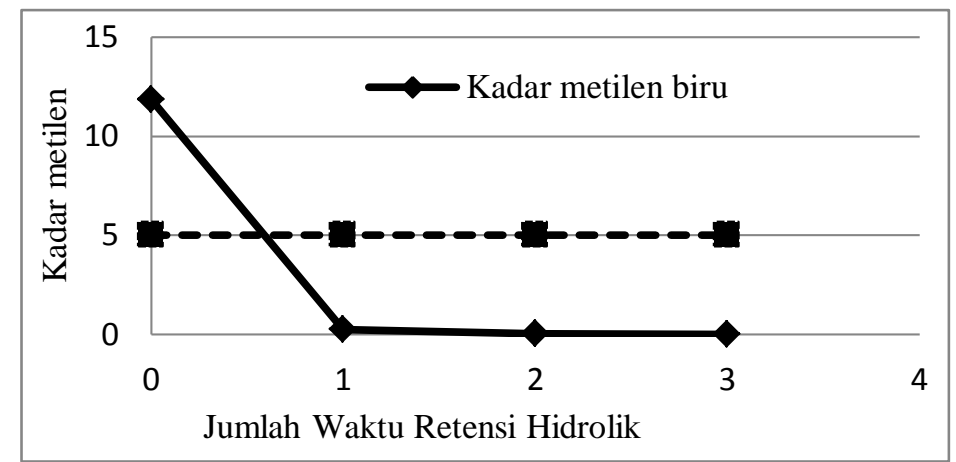

Gambar 2. Penurunan Kadar Metilen Biru

Berdasarkan Gambar 2. terjadinya penurunan dalam 3 kali waktu retensi hidrolik kemungkinan disebabkan karena masih tercukupinya nutrien oleh mikroorganisme untuk berkembang biak dan melakukan penguraian, serta melakukan mekanisme pertahanan diri agar tetap hidup (Gadd,1990). Mikroorganisme berperan dalam mendegradasi limbah metilen biru artificial, dimana kemungkinan mikroorganisme memecah senyawa metilen biru menjadi lebih sederhana. Hasil degradasi oleh mikroorganisme kemungkinan berupa unsur hara seperti unsur karbon (C) diserap oleh tumbuhan rumput gajah. Penurunan metilen biru dalam limbah artificial telah berada di bawah ambang batas baku mutu PERGUB Bali No 16 tahun 2016 , dimana kadar maksimum metilen biru yang diperbolehkan yaitu sebesar 5 ppm sedangkan hasil penurunan kadar limbah metilen biru mencapai 0,0285 ppm. Berdasarkan uji-t dengan membandingkan t-hitung dengan $t$ - tabel dengan taraf kesalahan 5\% maka nilai Ho diterima. Hal tersebut menunjukkan bahwa penurunan kadar metilen biru dengan biosistem telah berhasil. Efektivitas dan kapasitas biosistem vertikal dalam menurunkan kadar metilen biru dapat dilihat pada Tabel 2.

Berdasarkan Tabel 2. efektivitas biosistem vertikal maksimum diperoleh sebesar 99,7587\%. Kapasitas maksimum biosistem dalam menurunkan kadar metilen biru dalam limbah artificial sebesar 2,7512 $\mathrm{x} 10^{3} \mathrm{mg} / \mathrm{m}^{3}$. Jadi dalam $1 \mathrm{~m}^{3}$ biosistem dapat menurunkan kadar metilen biru dalam limbah artificial sebesar $2,7512 \times 10^{3} \mathrm{mg}$.

\section{Efektivitas dan kapasitas biosistem vertikal dalam menurunkan kadar Cd}

Penentuan kadar $\mathrm{Cd}$ dalam limbah artificial dapat disajikan pada Tabel 3 dan Gambar 3.

Tabel 2. Efektivitas dan Kapasitas Biosistem Vertikal dalam Menurunkan Kadar Metilen Biru

\begin{tabular}{ccc}
\hline Perlakuan & Ef. Rata-rata $(\%)$ & Kp. rata-rata $\left(\mathrm{mg} / \mathrm{m}^{3}\right)$ \\
\hline Limbah Awal & 0 & 0 \\
1 kali waktu retensi hidrolik & 98,7161 & $2,7225 \times 10^{3}$ \\
2 kali waktu retensi hidrolik & 99,6646 & $2,7486 \times 10^{3}$ \\
3 kali waktu retensi hidrolik & 99,7587 & $2,7512 \times 10^{3}$ \\
\hline
\end{tabular}


Tabel 3. Kadar Cd dalam Limbah Artificial

\begin{tabular}{ll}
\hline \multicolumn{1}{c}{ Perlakuan } & Kadar Limbah Cd Rata-Rata $(\mathrm{ppm}) \pm$ SD \\
\hline Limbah Awal & $13,8442 \pm 0$ \\
1 kali waktu retensi hidrolik & $0,1590 \pm 0,0121$ \\
2 kali waktu retensi hidrolik & $0,0821 \pm 0,0027$ \\
3kali waktu retensi hidrolik & $0,0275 \pm 0,0028$ \\
\hline
\end{tabular}

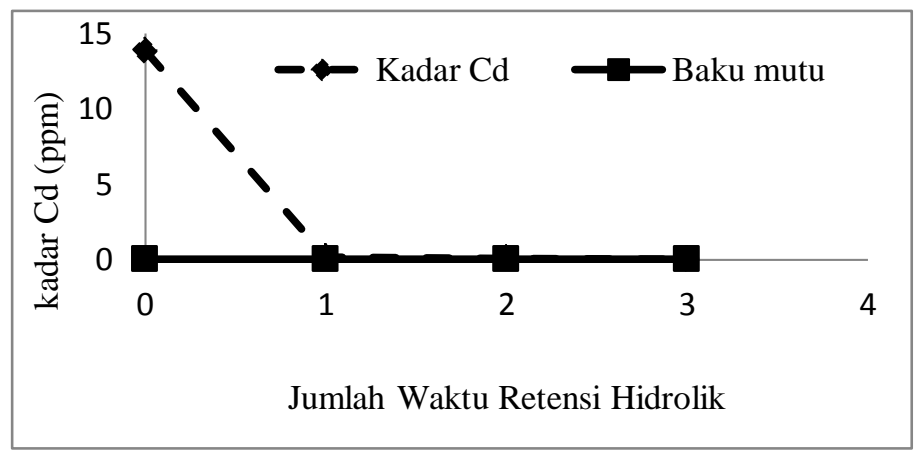

Gambar 3. Penurunan Kadar Cd

Peranan mikroorganisme dalam menurunkan kadar limbah $\mathrm{Cd}$ yaitu dengan cara mengikat logam berat pada struktur sel mikoorganisme tersebut. Terjadinya pengikatan ini disebabkan oleh permukaan sel mikroorganisme memiliki muatan negatif yang terbentuk dari struktur-struktur anion, sedangkan logam Cd memiliki muatan positif. Selain itu kemungkinan karena ukuran sel mikroorganisme kecil sehingga luas permukaan menjadi besar menyebabkan daya ikat logam $\mathrm{Cd}$ dengan permukaan sel mikroorganisme semakin tinggi (Mawardi et.al, 1997). Hal tersebut ditunjukkan pada Gambar 3, dimana terjadi penurunan dalam 3 kali waktu retensi hidrolik. Berdasarkan uji-t daerah penerimaan Ho diterima pada 3 kali waktu retensi hidrolik, sedangkan pada 1 dan 2 kali waktu retensi hidrolik nilai Ho ditolak. Berdasarkan hal tersebut penurunan kadar $\mathrm{Cd}$ dengan biosistem telah berhasil.

Efektivitas dan kapasitas biosistem vertikal dalam menurunkan kadar $\mathrm{Cd}$ dapat dilihat pada Tabel 4.

Berdasarkan Tabel 4, efektivitas biosistem mencapai $99,8011 \%$ dalam 3 kali waktu retensi hidrolik. Hasil tersebut menunjukkan bahwa efektivitas biosistem cukup baik dalam menurunkan kadar $\mathrm{Cd}$ dalam limbah artificial terhadap baku mutu PERGUB Bali no 16 tahun 2016. Nilai kapasitas maksimum biosistem dalam menurunkan kadar limbah $\mathrm{Cd}$ yang diperoleh sebesar $3,2220 \times 10^{3} \mathrm{mg} / \mathrm{m}^{3}$.

\section{Efektivitas dan kapasitas biosistem vertikal dalam menurunkan kadar $\mathrm{Cr}$ total}

Kadar $\mathrm{Cr}$ total dalam limbah artificial dibuat dengan kadar $15 \mathrm{ppm}$, pada alat AAS terukur sebesar 15,4255 ppm. Hasil yang yang diperoleh dapat dilihat pada Tabel 5 dan kurva penentuan kadar $\mathrm{Cr}$ total artificial dapat disajikan pada Gambar 4.

Tabel 4. Efektivitas dan kapasitas biosistem vertikal dalam menurunkan Kadar Cd

\begin{tabular}{ccc}
\hline Perlakuan & Ef. Rata-rata $(\%)$ & Kp. rata-rata $\left(\mathrm{mg} / \mathrm{m}^{3}\right)$ \\
\hline Limbah Awal & 0 & 0 \\
1 kali waktu retensi hidrolik & 98,8515 & $3,1913 \times 10^{3}$ \\
2 kali waktu retensi hidrolik & 99,4069 & $3,2093 \times 10^{3}$ \\
3 kali waktu retensi hidrolik & 99,8011 & $3,2220 \times 10^{3}$ \\
\hline
\end{tabular}


Tabel 5. Kadar Cr Total Dalam Limbah Artificial

\begin{tabular}{ll}
\hline \multicolumn{1}{c}{ Perlakuan } & Kadar Limbah Cr Rata-Rata $(\mathrm{ppm}) \pm$ SD \\
\hline Limbah Awal & $15,4255 \pm 0$ \\
1 kali waktu retensi hidrolik & $5,6321 \pm 1,0489$ \\
2 kali waktu retensi hidrolik & $7,5782 \pm 0,5621$ \\
3 kali waktu retensi hidrolik & $10,1719 \pm 1,7593$ \\
\hline
\end{tabular}

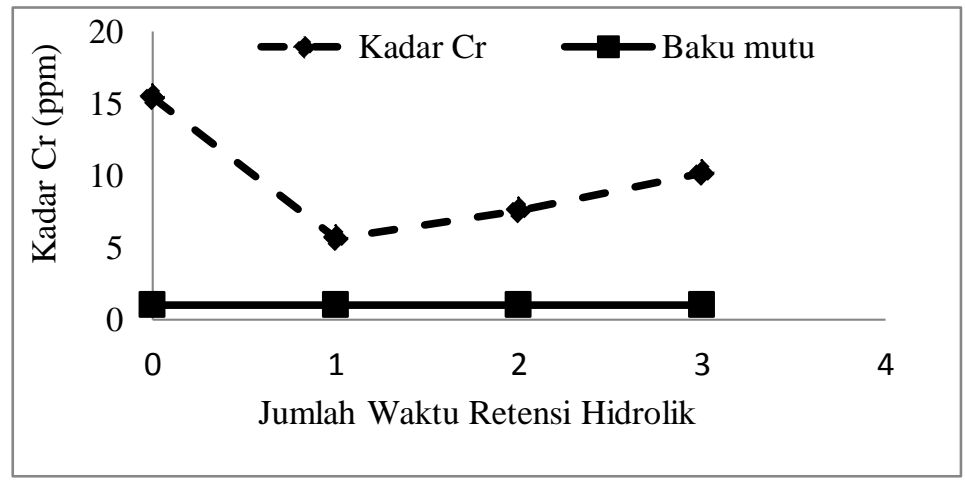

Gambar 4. Penurunan Kadar Cr Total

Berdasarkan Gambar 4. Terjadi penurunan kadar $\mathrm{Cr}$ dalam 1 kali waktu retensi hidrolik, dengan kadar $\mathrm{Cr}$ diperoleh sebesar 5,6321 ppm. Terjadinya penurunan kadar kemungkinan mikroorganisme mengikat logam $\mathrm{Cr}$ pada dinding sel. Terjadinya pengikatan ini disebabkan karena permukaan sel mikroorganisme memiliki muatan negatif yang terbentuk dari struktur-struktur anion, sedangkan logam $\mathrm{Cr}$ memiliki muatan positif (Mawardi et.al, 1997). Pada 2 kali dan 3 kali waktu retensi hidrolik mengalami peningkatan kadar $\mathrm{Cr}$ total dibandingkan 1 kali waktu retensi hidrolik, dengan kadar yang diperoleh masing-masing sebesar 7,5782 ppm dan $10,1719 \mathrm{ppm}$. Adanya peningkatan kadar $\mathrm{Cr}$ kemungkinan juga disebabkan oleh adanya proses pelepasan, dimana logam $\mathrm{Cr}$ yang tertahan sementara pada biosistem kemudian ketika dialiri limbah lagi pada 2 dan 3 kali waktu retensi hidrolik logam $\mathrm{Cr}$ ikut turun bersama air limbah.

Penurunan kadar $\mathrm{Cr}$ kurang baik dibandingkan dengan penurunan kadar $\mathrm{Cd}$ kemungkinan disebabkan oleh nomor atom $\mathrm{Cr}$ (24) lebih kecil daripada logam Cd (48). Nomor atom $\mathrm{Cr}$ yang kecil menyebabkan logam $\mathrm{Cr}$ lebih sulit untuk diadsorpsi oleh media dibandingkan dengan logam $\mathrm{Cd}$. Selain itu jika dilihat dengan elektronegatifan, elektronegatif $\mathrm{Cr} \quad(1,66)$ lebih kecil dibandingkan dengan logam $\mathrm{Cd} \quad(1,69)$ sehingga memungkinkan daya ikat $\mathrm{Cr}$ terhadap mikroorganisme lebih lemah daripada logam Cd. Hasil analisis menggunakan uji-t deskriptif yaitu nilai Ho pada masing-masing waktu retensi hidrolik ditolak. Hasil penurunan kadar limbah $\mathrm{Cr}$ total dengan biosistem masih berada diatas baku mutu PERGUB BALI No 16 tahun 2016 yakni sebesar 1 ppm. Hal ini menunjukkan bahwa penurunan kadar $\mathrm{Cr}$ total dalam limbah artificial dengan biosistem kurang baik walaupun bisa menurunkan hingga 5,6321 ppm.

Efektivitas dan kapasitas biosistem vertikal dalam menurunkan kadar $\mathrm{Cr}$ total dapat dilihat pada Tabel 6.

Efektivitas biosistem dalam 3 kali waktu retensi hidrolik masing-masing diperoleh sebesar $63,4927 \%, 50,8781 \%$, dan 34,0662\%. Hasil tersebut menunjukkan bahwa efektivitas biosistem kurang baik dalam menurunkan kadar $\mathrm{Cr}$ total dalam limbah artificial terhadap baku mutu PERGUB Bali no 16 tahun 2016. Kapasitas maksimum diperoleh sebesar $2,2842 \times 10^{3} \mathrm{mg} / \mathrm{m}^{3}$. 
Tabel 6. Efektivitas dan kapasitas Biosistem Vertikal dalam Menurunkan Kadar Cr total

\begin{tabular}{ccc}
\hline Perlakuan & Ef. Rata-rata $(\%)$ & Kp. rata-rata $\left(\mathrm{mg} / \mathrm{m}^{3}\right)$ \\
\hline Limbah Awal & 0 & 0 \\
1 kali waktu retensi hidrolik & 63,4927 & $2,2842 \times 10^{3}$ \\
2 kali waktu retensi hidrolik & 50,8781 & $1,8351 \times 10^{3}$ \\
3 kali waktu retensi hidrolik & 34,0662 & $1,2285 \times 10^{3}$ \\
\hline
\end{tabular}

\section{SIMPULAN DAN SARAN}

\section{Simpulan}

Suspensi aktif terbaik dengan pertumbuhan biomassa mencapai $1200 \mathrm{mg} / \mathrm{L}$ pada sumber nutrien pupuk NPK(pasaran) dan NPK. Efektivitas biosistem dalam menurunkan kadar metilen biru, $\mathrm{Cd}$, dan $\mathrm{Cr}$ total berturutturut sebesar 99,7587\%, 99,8011\%, dan 63,4927\%. Kapasitas maksimum biosistem dalam menurunkan kadar metilen biru, $\mathrm{Cd}$, dan $\mathrm{Cr}$ total masing-masing sebesar $2,7225 \times 10^{3}$ $\mathrm{mg} / \mathrm{m}^{3}, 3,1913 \times 10^{3} \mathrm{mg} / \mathrm{m}^{3}$, dan $2,2842 \times 10^{3}$ $\mathrm{mg} / \mathrm{m}^{3}$, biosistem vertikal dengan rumput gajah sudah mampu menurunkan kadar metilen biru hingga $\leq 5 \mathrm{ppm}$ dalam 1 kali waktu retensi hidrolik dan menurunkan kadar $\mathrm{Cd} \leq 0,05 \mathrm{ppm}$ dala 3 kali waktu retensi hidrolik, akan tetapi tidak mampu menurunkan kadar $\mathrm{Cr}$ total $\leq 1 \mathrm{ppm}$.

\section{Saran}

Perlu dilakukan penelitian menggunakan parameter lain seperti $\mathrm{pH}, \mathrm{DO}$ dan lain-lain, serta perlu dilakukan penelitian lebih lanjut senyawa yang terbentuk hasil degradasi metilen biru oleh mikroorganisme.

\section{UCAPAN TERIMAKASIH}

Penulis mengucapkan terimakasih kepada LP3M atas hibah skema grup riset. Terima kasih juga disampaikan kepada staf dan laboran laboratorium Kimia Lingkungan Program Studi Kimia FMIPA Universitas Udayana yang telah membantu kelancaran pelaksanaan penelitian ini.

\section{DAFTAR PUSTAKA}

Atlas, R. M., and Bartha,R., 1987, Microbial Ecology: Fundamentals and Aplication, $2^{\text {nd }}$ ed, The Benjamin / Cummings Publ, Co., Inc., Menlo Park.

Avudainayagam, S., Megharaj, M., Owens, G., Kookana, R.S., Chittleborough, and Naidu, R., 2003, Chemistry of Chromium in Soils with Emphasis on
Tannery Waste Sites, Reviews of Environmental Contamination and Toxicology, 178: 53-91.

Fortsner, U., dan Wittman G.T.W., 1983, Metal Pollution In The Aquatic Environment, Springer-Verlag, Berlin.

Gadd, G.M., 1990, Metal Tolerance, McgrawHill, New York.

Ginting, P., 2007, Sistem Pengolahan Lingkungan dan Limbah Industri, Yrama Widya, Bandung.

Gosal, R., 2017, Biodegradasi Zat warna Remazol Yellow fg dalam Sistem Mikrobial, Skripsi, Universitas Udayana, Bali.

Hartesa, F., 2016, Biodegradasi Zat Warna Remazol Black B Secara AerobikAnaerobik Dalam Sistem Biofiltrasi Vertikal Dengan Menggunakan Tanaman Talas (Colocasiaesculenta), Skripsi, Universitas Udayana, Bukit Jimbaran.

Hawley, 1981, Condensed Chemical Dictionary $8^{\text {th }}$ edition, Van Nortrand Reinhold, New York.

Kriswidatari, L.P., 2016, Biodegradasi Remazol Brilliant Blue Dalam Sistem Biofiltrasi Vertikal Dengan Inokulum Bakteri Dari Sedimen Sungai Mati Imam Bonjol Denpasar, Skripsi, Universitas Udayana, Bukit Jimbaran.

Macchi, G., Pagano,M., Pettine, M., Santori, M., and Tiravanti, G., 1991, A bench Study on Chromium Recovery from Tannery Sludge, Water Research, 25(8) : 1019-1026.

Mawardi, Sugiharto,E., Mudjiran, dan Prijambada, I.D., 1997, Biosorpsi Timbal Oleh Biomassa Saccharomyces cerevisiae, BPPS-UGM, 10 (2C) :203213.

Meita, S.D., 2015, Pemanfaatan Biosistem Tanaman untuk Menurunkan Kadar Fenol, Amonia, Ion Klorida, dan COD, dari Proses Biodegradasi Air Limbah yang Mengandung Rhodamin B, Thesis, Pascasarjana Universitas Udayana, Bali. 
Inokulasi Suspensi Aktif pada Biosistem Vertikal dengan Tumbuhan Rumput Gajah (Pennisetum Purpureum) dalam Penurunan Kadar Metilen Biru, Cd dan Cr Total (I W. B. Suyasa, N. G. A. M. D. A. Suastuti, dan I G. M. A. P. Raharja)

Soeparno, 1992, Ilmu dan Teknologi Daging, Gajah Mada Press, Yogyakarta.

Suyasa, W.B., dan Dwijani, W., 2011, Pengaruh Penambahan Urea, Kompos Cair, Dan Campuran Kompos Dengan Gula Terhadap Kandungan BOD dan COD Pada Pengolahan Air limbah Pencelupan, Jurnal Ecotrophic, 4(1): 62-65.
Waluyo, L., 2009, Mikrobiologi Lingkungan, UMM Press, Malang.

Widyati, E., 2013, Memahami Interaksi Tanaman-Mikroba, Jurnal Tekno Hutan Tanaman, 6(1) : 13-20. 